\title{
The Javanese Onomatopoeic Words Concerning Human Sense, Head and Eye Movements
}

\author{
Sunarya \\ Universitas PGRI Semarang, Indonesia \\ Email: sunaryo@upgris.ac.id
}

\begin{abstract}
Onomatopoeic words in the Javanese language are evidence of the uniqueness of both lingual aspects and the described facts. This study discussed the phenomenon of phonological and morphological language processing. This study examined the derivation of the onomatopoeic root words of Javanese into some form of the word as an iconic formation. The data source covered source language of local print media. The study found that the iconic words to denote the head movements are classifiable into two types of motion. The first, the head movement itself is without involving the other elements; second, the head movement which involves other elements. Head movements that do not involve other elements include the motions of up and down, like: manthuk [mantu?] 'nodding', lenggut-lenggut[lə⿹gut-ləygut] 'nodding', and ndhingkluk [ndiinklu?] 'down'; right and left lateral movements, such as: gedheg[geḍcg]. Additionally, head movements that involve other elements are described by a word sundhul[sundUl]. The iconic nature of several words for eyes movements are words such as mlorok [mloro?], kedhep [kəḍcp], nglirik [nlirl?], liyer-liyer [lijər-

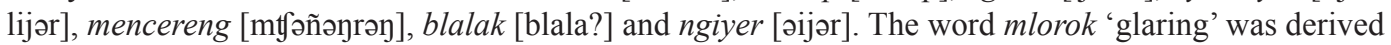
from basic word plorok with addition of prefix $a N-$, and comes from the root rok.
\end{abstract}

Keywords: iconic words; onomatopoeia; language; phonology and morphology

\section{INTRODUCTION}

Saussure (2001) is renowned as the founder of the study of signs or semiotics, although Saussure himself did not call the concept Semiotics, but Semiology. Saussure (2001) as quoted by Berger (2005, pp. 6) says that language is a system of signs that enable one to express thoughts or ideas, and can, therefore, be compared with the system of writing, the alphabet of the deaf, symbolic rituals, the politeness formula, and military signals, etc. Furthermore, Saussure argued that the field of science is part of social psychology and thus part of the general psychology and can generate another discipline; what he termed Semiology (derived from the Greek word, semeion, means "a sign"). From the Saussurean perspective, Semiology shows what constitutes within the signs and the rules to determine them (Saussure, 2001, p. 16). Regarding the link between linguistics and
Semiology, Jakobson (1965, pp.23) explains that in the Saussurean view, linguistics is part of Semiology and the latter determines the characteristics and nature of what distinguishes a language into a separate system within the totality of Semiological facts.

According to Saussure (cited in Bredin, 1984, p. 67), the sign of language is the primary unit, since language is only a large number of pins that are connected to each other through a variety of ways. In the Seeaussurean view, the signs of a language shall not combine an object with its name, but the concept and sound image. The combination of the concept and sound image is a sign or a compilation of signs. The internal structure of the sign in Saussure's point of view is binary or dyadic which cover the slices of the image of the sound. At the end Saussure (2001) called it the signifier (signifiant) or marker and then sliced 
concept Saussure called markers or signified (signifie). In the Saussurean view, the sound image is not a physical phenomenon like the sounds of language by which we communicate, but rather psychological one. He further argues that the interrelation between sound and image lays an insparable link to thought (Saussure cited in Leitch, 2001, p.976). Saussure saw the signifier and signified relationships were like two sides of the same coin, inseparable to one another. When we see the signifier $X$, the only thing we can bear in our minds is the concept of $X$. Conversely, if we think about the concept $\mathrm{Y}$, the thing that comes up in our minds is the signifier Y.

Saussure (cited in Bredin, 1984, pp. 76) also questions the signs like TABLE, which is used in a variety of different places to identify the concept or meaning of the table. According to Saussure, we need to distinguish the signification and values of the signs. Signification is a concept that we attach to a sign. We use the word 'TABLE' to represent a kind of household furniture or office furniture. The base for writing or work is the process of signification. The value of a sign is the object's relationship with other signs.

Dwight Whitney defines language as a sign system, which is arbitrary and conventional. Dwight Whitney's notions of signs are in line with Jakobson's (1965, p.24) and Saussure's (2001) notions that the relationship between form (signifier) and meaning (signified) is arbitrary or conventional. That is, there is no logical or scientific reason whatsoever why a sign $X$ is used to represent the sign $\mathrm{Y}$, or why the word SAPI in Indonesian is used to refer to a COW in English. Although the arbitrary relationship bears important characteristics of the sign, Saussure acknowledges the existence of a natural sign or motivated sign as an onomatopoeia and sound symbolism. The arbitrariness or the motivated sign according to Saussure is beyond absolute, and is instead just a matter of degree. The creation of new words like slithy of slimy and lithe and signs are which associated them have constellation of words and meanings equally bound by the same sounds as bash, mash, smash, crash, dash, lash, hash, rash, brash, clash, trash, plash, splash and flash. These words are among the onomatopoeic signs and are classifiable into the iconic signs (Jakobson, 1965, p. 32).

Both Saussure and Jakobsonian (1965, pp.14) thoughts about signs are elaborated in a brief description above which has triggered studies on the iconic sign that is extraordinary in language, literature or other fields. Linguists who engage in this school have attempted to find empirical evidence for the widest variety of signs reflecting the similarities between signifier and signified, often referred to as iconicity. In addition to the study of onomatopoeia, which is a signifier created through imitating reference on them in nature such as the sounds of dor, tar, tick, boom, wek-wek, bleating, roaring, hissing, another developing study of iconicity is the symbolism of sound. This is also often called phonesthemes , a series of sounds that can be vocalized in to the categories of semantically liquid and more expressive (Jakobson and Waugh, 1979) or the groupings of similar meaning about the same sound (Bolinger, 1965). In other words phonesthemes is a group of language sounds that share similarities in terms of meanings. As reported by Imai et al. (2008, pp.65), the Indo European languages such as English, sound symbolism or phonesthemes are found as in the squeeze, squirt, squint, bump, thump, and plump (e.g., Firth, 1935/1957). Meanwhile, a systematic relationship between the amount of certain phonemes and meanings are also found as the words that begin with ' $g l$-' which implies something that is visually as in glance, glare, gleam and glimmer (Bloomfield, 1933/1984). In Japanese, Imai et al. (2008, pp. 55) reported the existence of sound symbolism in mimesis not only on onomatopoeia to refer the animal sounds (like miau, the sound of a cat), but also words that refer to events or circumstances in which a sound is considered unimportant. I.e., the consonant / $\mathrm{g}$ / is used to describe a rolling heavy objects like the "goro", while the lightweight object that rolls .applied a consonant / k / as in "koro". Consonants / b / are used to describe a large amount of liquid falling on a solid surface such as in "bota", while the consonant / $\mathrm{p} /$ is used to refer to a small amount of liquid falling on a solid surface such as the word "pota". In the Indonesian language, symbolism sounds are also found where the vowel ending in / i / or / e / usually used to indicate the small things or something trivial and less important, while the vowel / o / or / u / to represent round, long, large or cylindrical objects. Words such as pentil 'nipple', kutil 'wart', pimples, sassy, dwarf, and Moron have smaller meanings or are not too important.

In addition to the principle of iconicity as mentioned previously, there are some other opinions that show that iconicity is not a rare phenomenon. In reality, the symptoms are easily found universally anywhere and in any language. Sound imitations that represent senses or motions normally refer to a 
moving object or a motion in general. In Javanese, to adjectively describe the entity of 'much' (usually refers to uncountable things), then we are using expressions or onomatopoeic sounds, thus such an expression becomes more affective to the speaking partner(s). The senses described by motions through onomatopoeic sounds are very productive in nature. Almost all parts of the human body can be moved, starting from the top to the bottom, and are classifiable like onomatopoeic words, referring to head and eyes movements.

\section{Review of Related Literature}

A number of studies on onomatopoeic words use in Javanese have only reviewed "the surface aspects" of the words, among others a research conducted by Mulyani (2014) in her article "onomatopoeia in the Novel of Emas Sumawuring Baluwarti a work by Partini, B." who identified onomatopoeic words in four categories: a) the imitative sounds of an object, b) the sound imitations of animals, c) imitations of natural sounds, and d) human sound imitations. In addition, she described four categories based on their forms and functions. Subroto (1981) reviewed a small portion of the Javanese onomatopoeic words from the phonestemic aspects (Sudaryanto, 1989, p. 52). The findings conclude that the phonemic vowels / i /, / u /, and $/ \mathrm{o} /$ in the affective words of JL enables the users to show little nuances of things ranging from somewhat large, larger and great, i.e. the words methingil 'small looked', methungul'somewhat bigger looked', and methongol'a giant looked'; ithir-ithir'a little pouring', uthur-uthur'a rather much pouring', and othorothor'a great pouring' (Subroto, 1981). ÅsaAbelin (1999) in his doctoral dissertation 'Studies in Sound Symbolism 'examined the nature of onomatopoeic sounds in Swedish, termed the onomatopoeia to mean all kinds of sound imitations, while phonestheme is the bound sub-morphemic strings (e.g. consonant clusters) which share certain elements of meaning or function. For him the relationship between sound and meaning is often iconic or indexical, as well as symbolic. At least, Abelin (1999) concluded that the sound symbolism referred to general phenomenon of motivated relations between sound and meaning, including onomatopoeias.

\section{METHODS}

This study was designed using a qualitative approach, since the analytical method engages both a phonological and morphological phenomenon of a language. It specifically examines the derivational root of the onomatopoeic words in Javanese which generate some forms of the iconic words. The data source is in the form of documents, such as Javanese print media such as Panjebar Semangat (labeled with P.S.), Jaya Baya (J.B), Djaka Lodang (D.L), and the Javanese literary work of Serat Wicarakeras (S.W). The other sources are information obtained from informants living around the areas of Surakarta and Yogyakarta. This study collects some data from ten informants. These informants are selected on the basis of certain conditions, especially those who linguistically understand information related to onomatopoeic words in Javanese. The data was collected through purposive questionnaires. The research data includes the clauses and sentences of JL representing the onomatopoeic words both in written and oral data sources. The data collection technique involves the techniques of reading and listening, taking notes, recording technique, distributing questionnaires.

The method used in this study follows a linguistic model of research proposed by Sudaryanto (2001), in his book entitled "Metodedan Aneka Teknik Analisis Bahasa" (Trans. Methods and Various Techniques of Language Analysis), namely the method of agih and padan. The method of agih is a language analysis which directly links the elements within the language itself, regardless of the elements outside of the language. This method employs the basic technique for the direct element (Bagi Unsur Langsung /BUL), which directly analyzes the lingual unit of the studied material. Furthermore, advanced techniques such as lesap (vanished) technique, substitution technique, expansion technique, and technique of sisip (insert) (Sudaryanto, 2001, pp.13-17) were used.

\section{FINDINGS AND DISCUSSION \\ Head Parts of Movement}

The head has several elements that can be moved. Each movement of the head can be described by the iconic words in the table 1.

\section{Head Movements}

The iconified head movements, as described above, are classified into two types of motion. The first, the head movement itself is without involving the other elements; second, the head movement which involves 
Table 1. List of the iconic words for head movements

\begin{tabular}{|c|c|}
\hline Head Parts & Iconic Movement \\
\hline \multirow{5}{*}{ Head } & manthuk [manțU?] 'nodding' \\
\hline & gedheg [geḍg] 'a nodding head' \\
\hline & sundhul [sunḍUl] 'head touching that on it' \\
\hline & lenggut-lenggut [ləygut- ləygut] 'niddle-noddle' \\
\hline & ndhingkluk [ndijklU?] 'bow down \\
\hline
\end{tabular}

Notes:

These labels referred to the documents used in this study. These data obtained from the Javanese language of print media such as Panjebar Semangat (labeled with P.S.), Jaya Baya (J.B), DjakaLodang( D.L), and the Javanese literary work of SeratWicarakeras (S.W).

other elements. Head movements that do not involve other elements include the motions of up and down, like: manthuk [mantu?] 'nodding', lenggut lenggut [ləygut-ləngut] 'nodding', and ndhingkluk [ndiinklu?] 'down'; right and left lateral movement, such as: gedheg [gedeg]. Additionally, head movements that involve other elements are described by a word sundhul [sundUl] (cf. Sunarya, et al., 2017)

The word manthuk' nodding', derived from the root anthuk which can attach to a prefix an-, to form an active verb. The word comes from the root word Thuk [tuk], namely in the form of imitation sounds, falls in the category of "punching" (DA (SY): B.16). Head movement in the up and down direction with icons manthukor anthuk, the actual depiction of the movement is not directly from the sound thuk, because the movement does not produce any noise Thuk, but the association of sound was borrowed to describe the movement that is "as if" producing sound like thuk (cf. Sunarya, et al., 2017).

The word lenggut-lenggut [ləygut-ləygut] 'nodding vigorously' is a reduplicated form of the basic word lenggut. It can be equated with the word manggut [mangut] 'nodding' and ngglegut [nglogut] 'nodding' (TPBBY, 2011, p. 245-489), which has the same meaning and is derived from the root word gut [gut]. The root word gut can be aligned with the root word $g u k[\mathrm{gu}]$ in the Indonesian word nod, or a nod which has the same meaning. The difference lies in the use of ending phoneme of $/ \mathrm{t} /$ and $/ \mathrm{k} /$. The symptoms of such replacement refers to the change on the non-consonant velar into the velar consonant of such kind often occur in the languages of the
Indonesian archipelago, such as the Minangkabauan language, and the languages of Mentawai, Makassar, Madurese, etc. Some of the examples, i.e. the word langit becomes langikin the language of Mentawai, the word for empat (four) is appek, especially in the language of Mandar, and ampek in Minangkabauan language (Sudarno, 1992, p. 78). It is unique in nature, that the imitation of the sound gut includes the psychological sound of moving up and down with a swinging head with continuity.

The word ndhingkluk [ndijklu?] 'to bow down' comes from the root word dingkluk which gets its prefix $a N$ - to form an active verb. The word comes from the root word in the form of sound imitation $k l u k$ [kluk], and has another variant $\mathrm{O}$ sound klik [klik], klek [klek], and klok [klok] the sound of a 'bell-sounded'(DA (SY): B.8). The sound includes the category of "a fracturing thing". The sound of a "fracture" is further associated to describe the movement of the head down, which produces sound of a fracturing object, kluk.

The word gedheg [geḍg] ' head shakes shaking' and mlengos [mleyos] 'turning of head', are iconified words that share the same direction of head motions, which is a sideways movement. The word gedheg comes from the sound dheg, a sound that conveys that an object and 'heavy' and 'large'. This works in opposition with the sound word thek, conveying a sound of "small" and 'mild' object. The sound in the category of "a blowing/striking" (DA (SY): B.16). The sound for $d$ heg is then used to describe the movement of the head sideways, right, and left in continuity, which emits a sound like $d$ heg. 
The head movements have to do with other elements, such as sundhul [sunḍI] 'such head touches another object above it'. The word sundhul is derived from the root word $d h u l$ [dul], i.e. the imitation of a psychical sound for "round object collision". The sound 'dhul' is associated with the movement of the head that touches the object above it. In order to simplify the explanation of head movements, the given picture demonstrates the aforementioned head movements:

Figure 1

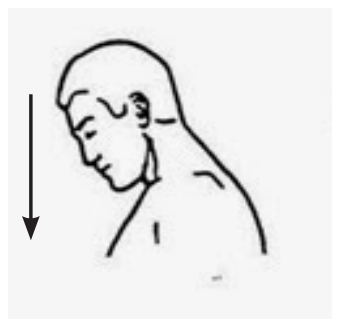

Figure 3

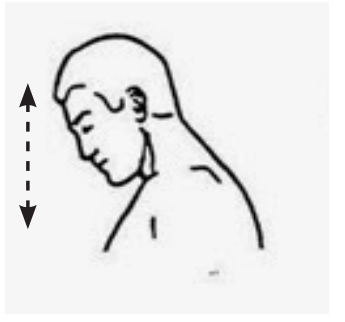

Figure 2

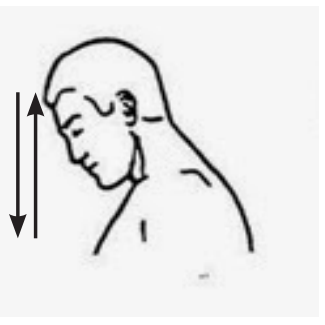

Figure 4

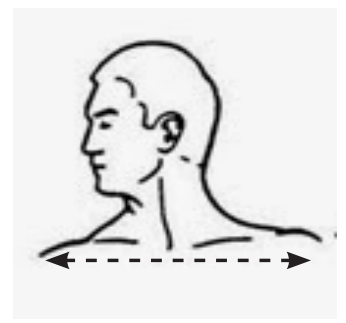

\section{Note}

Figure 1. ndhingkluk (head goes downward)

Figure 2. manthuk (head goes to down, then back again)

Figure 3. Lenggut lenggut (head continually swings up and down)

Figure 4. gedheg (head continually moves right and left)

Source: https://pixabay.com

\section{Eye Movements}

Figure 5. mlorok

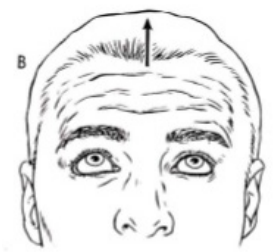

Figure 6. nglirik

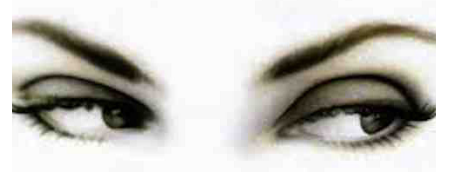

Table. 2. List of the iconic words for eyes movements

\begin{tabular}{|c|c|}
\hline Head Parts & Iconic Movements \\
\hline \multirow{8}{*}{$\begin{array}{c}\text { Eyes } \\
\text { Movements }\end{array}$} & mlorok [mloro?] 'glarring eyes \\
\hline & kedhep [kəḍp] 'blinking eyes' \\
\hline & nglirik [ylirI?] 'stealing a glance' \\
\hline & $\begin{array}{c}\text { liyer-liyer[lijər- lijor] 'eyes almost } \\
\text { closed due to sleepiness' }\end{array}$ \\
\hline & $\begin{array}{l}\text { mentheleng [mənțləy] 'looking } \\
\text { seriously without blinking' }\end{array}$ \\
\hline & $\begin{array}{c}\text { mencereng [məñtfərəク] 'looking at } \\
\text { sharply' }\end{array}$ \\
\hline & ngiyer [yijər] 'squinting eye' \\
\hline & $\begin{array}{c}\text { mblalak[mblala?] 'keeping eyes } \\
\text { wide-awake }\end{array}$ \\
\hline
\end{tabular}

The eyes movements shown above describe the iconic nature of several words, i.e. mlorok [mlors?], kedhep [kəḍcp], nglirik [nlirI?], liyer-liyer [lijər-lijər], mencereng [mtəñəทrəท], blalak [blala?] and ngiyer [əijər]. The word mlorok 'glaring' was derived from basic word plorok with the addition of prefix $a N-$, and comes from the root rok. If the root word rok is returned as a sound imitation, as in the word [koro?], which is 'a garden frog's sound' or 'a scratching sound' which has been previously discussed, then the sound rok in mlorok experienced a lot of shift in meaning. Thus as can be said, the root word rok is not onomatopoeic, rather more affective in nature. The root rok based on its affective value is largely determined by the vowel $o$, which has 'a great' feeling and can be matched with a small vowel $i$. This means the word nglirik was derived from the root word rik]. The notion use of nuance for 'great' describes in the wide eye openings as exemplified by the word mlorok, and the use of 'small' nuances to describe smaller eye openings exemplified by the word nglirik. The difference of them is the eye movement mlorok only centered on the eyelid, which is wide opened, while the word nglirik describes the direction of movement sideways view.

The word kedhep 'blinking' comes from the root word dhep[dep] and along with addition of formative to. The root word dhep is an imitation of a psychological sound, i.e. the sound eye movements of continually open and close. Thus, the word kedhepdirectly describes the movement of the opening and closing eyelid.

The word liyer-liyer 'eyes almost closed due 
to sleepiness' comes from the basic word liyer which is then reduplicated. The word liyer comes from the root word yerie imitation sounds of movement "as if spinning". Imitation sounds "as if spinning" are used to describe a sleepy person, or for a sense of "dizziness" as expressed in the word nggliyer [nglijor] (TPBBY, 201, pp. 248). Because the habit of the sleepy person is somewhat obscured, the concept of "sleepy" or "as if spinning" " originally iconified with yer sound imitation, then the iconification shifted into "somewhat closed eyes", as portrayed by the word ngiyer or kiyer 'his/her eyes somewhat closed'.

Figure 7. ngiyer

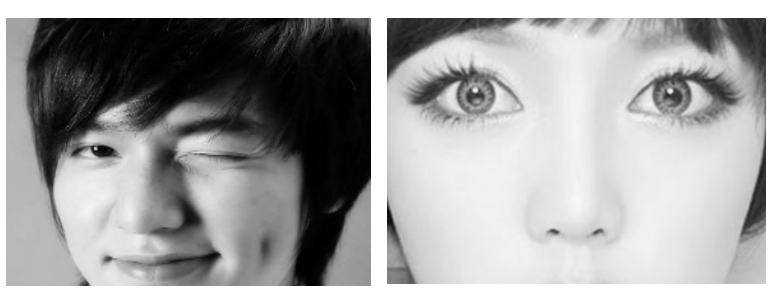

The word blalak means widely opened 'eyes', the process of its formation comes from the root blak repeated after, which is blakblak. For the most part, the rule of such a basic word formation made by repeating the root (see form and the process of formation of the word by repeating the root word in above), the last consonant at the first root is omitted, thus becoming blablak. But because in terms of the "stiffing "pronunciation sense, $b$ consonant was removed from blalak. The blak root is an imitation sound categorized in the "opening" movement, which has a variation of bass sound (D.A. (S.Y): B.10). This "opening" imitation is then associated with "widely -opened eyes".

\section{CONCLUSION}

The arbitrariness or the motivated aspects of a sign according to Saussure is just a matter of degree. Creation of new words like slithy of slimy and lithe and a sign that has a constellation of words and meanings equally bound by the same sound as bash, mash, smash, crash, dash, lash, hash, rash, brash, clash, trash, plash, splash and flash are among the onomatopoeic signs that can be classified as an iconic sign. Such evidence also found in the language of Java wherein the iconic words of head movements can be described in a few words; these categories are in fact, classifiable into two types of motion. The first, the head movement itself is without involving the other elements; second, the head movement which involves other elements. Head movements that do not involve other elements includes the motions of up and down, like: manthuk [mantu?] 'nodding', lenggutlenggut [ləygut- ləygut] 'nodding', and ndhingkluk [ndiinklu?] 'down'; right and left lateral movement, such as: gedheg [ged $\varepsilon g]$ 'not easily feel ashamed'. In addition to the head movement which involves other linguistic elements is described by a word sundhul [sundUl]. The iconic nature of several words for eyes movements are words such as mlorok [mlors?], kedhep [kəḍcp], nglirik [ylirI?], liyer-liyer [lijərlijər], mencereng [mtəñəทrəџ], blalak [blala?] and ngiyer [əijər]. The word mlorok 'glaring' was derived from basic word plorok with addition of prefix $a N$-, and comes from the root rok. If the root word rok is returned as a sound imitation, as in the word [koro?] which is 'a garden frog sound' or 'a scratching sound' which have been earlier discussed, then the meaning of rok sound of mlorok shifted a lot of far.

\section{ENDNOTES}

1) Householder $(1946,11)$ in the Oxford Dictionary of English Etymology (1967) explains that the consonant "wr" in many words of the World implies the meaning of "spinning or whirling" can be paired with a consonant of $r$ in the Javanese language, such as words muser, muter, gliyer, etc.

\section{REFERENCES}

Abelin, Åsa (1993). Studies in Sound Symbolism. Doctoral Dissertation. Stora Hörsalen, Humanisten: Göteborg University.

Bloomfield, L. (1984). Language. Chicago: University of Chicago Press (Original Work published 1933).

Bolinger, D. (1965). Forms of English: Accent, Morpheme,Order. Tokyo: Hokuou Publishing Company.

Bredin, H. (1984). Sign and Value in Saussure. Philosophy, 59, 67-76.

Firth, J. R. (1957). The use and distribution of certain English sounds.In J. R. Firth (Ed.), Papers in linguistics 1934-1951 (pp. 34-46). London: Oxford University Press (Reprinted from Firth, J. R. (1935), English Studies, 17, pp. 2-12).

Jakobson, R., Waugh, L. (1979). The sound shape of language. Sussex: Harvester Press.

Leitch, V. B. (2001). The Norton anthology of theory and criticism. New York: Norton. 
Mulyani, IsnaSiti. (2014). Onomatope dalam Novel Emas Suwawuring Baluwarti karya Partini, B. Jurnal Program Studi Pendidikan Bahasa and Sastra Jawa Universitas Muhammadiyah Purworejo, 1(5).

Imai, M., Kita, S., Nagumo, M., Okada, H. (2008). Sound symbolism facilitates early verb learning. Cognition, 109, 54-65.

Saussure, F. de. (2001). Course in General Linguistics. Beijing: Foreign Language Teaching and Research Press.

Subroto, Edi (1981). The Onomatopoeic Words and Phonethemes in Javanese Language. The International Conference of Austronesian Language. Denpasar, Bali, on January $19^{\text {th }}-24^{\text {th }}$ 1981.
Sudaryanto (1982). LaporanPenelitian: "Kata-kata Afektif dalam Bahasa Jawa”. Yogyakarta: Proyek Penelitian Bahasa and Sastra Indonesia and Daerah. [Research Report: The Affective Words in Javanese Language]. Daerah Istimewa Yogyakarta.

Sunarya, Sumarlam, Sahid Teguh, W., Sri Marmanto (2017). Development of Non-arbitrary to the Arbitrary Iconic Words in Javanese Language. Gema Online Journal of Language Studies, 17(3), 137-151. Retrieved from: http://ejournal.ukm. my/gema/issue/view/999 